\title{
Sources and spatial distribution of heavy metals in scleractinian coral tissues and sediments from the Bocas del Toro Archipelago, Panama
}

\author{
Kathryn L. E. Berry • Janina Seemann • \\ Olaf Dellwig • Ulrich Struck • Christian Wild • \\ Reinhold R. Leinfelder
}

Received: 31 October 2012 / Accepted: 26 April 2013 /Published online: 31 May 2013

(C) The Author(s) 2013. This article is published with open access at Springerlink.com

\begin{abstract}
Marine ecosystems worldwide are threatened by aquatic pollution; however, there is a paucity in data from the Caribbean region. As such, five heavy metals (arsenic, cadmium, copper, zinc, mercury) were measured in tissues of the scleractinian corals Porites furcata and
\end{abstract}

K. L. E. Berry $(\bowtie)$

Catchment to Reef Research Group, Centre for Tropical Water \& Aquatic Ecosystem Research (TropWATER), James Cook University, Townsville QLD 4811, Australia e-mail: kathrynaberry@gmail.com

J. Seemann $\cdot$ R. R. Leinfelder

Department of Geological Sciences, Freie Universität Berlin, Malteserstr. 74-100, 12249 Berlin, Germany

e-mail: jseemann@zedat.fu-berlin.de

R. R. Leinfelder

e-mail: reinhold.leinfelder@fu-berlin.de

O. Dellwig

Leibniz Institute for Baltic Sea Research (IOW), Seestraße. 15, 18119 Rostock, Germany

e-mail: olaf.dellwig@io-warnemuende.de

U. Struck

Museum für Naturkunde, Leibniz Institute for Research on Evolution and Biodiversity, Invalidenstraße 43, 10115

Berlin, Germany

e-mail: ulrich.struck@mfn-berlin.de

C. Wild

University of Bremen (FB 2 Biology and Chemistry) and Leibniz Center for Tropical Marine Ecology (ZMT),

Fahrenheitstraße. 6, 28359 Bremen, Germany

e-mail: christian.wild@uni-bremen.de
Agaricia tenuifolia and in adjacent sediments in the Bocas del Toro Archipelago, Panama. Samples were collected from five reef sites along a gradient of distance from an international shipping port and were analysed using inductively coupled plasma optical emission spectrometry and atomic absorption spectrophotometry for mercury. Copper and zinc were the most abundant metals and ranged from 11 to $63 \mathrm{mg} \mathrm{kg}^{-1}$ and from 31 to $185 \mathrm{mg} \mathrm{kg}^{-1}$ in coral tissues, respectively. The highest concentration of each metal was measured in $P$. furcata tissues, with copper and mercury concentrations significantly higher in $P$. furcata than in A. tenuifolia at every site. These results suggest that $P$. furcata has a higher affinity for metal accumulation and storage than $A$. tenuifolia. With the exception of cadmium, metal concentrations in coral tissues were generally elevated at coral reefs in closer proximity to the port; however, this pattern was not observed in sediments. Hard coral cover was lowest at reefs in closest proximity to the port, suggesting that metal pollution from port-related activities is influencing hard coral abundance at nearby coral reefs.

Keywords Coral reef · Heavy metal · Sediments · Port $\cdot$ Porites furcata $\cdot$ Agaricia tenuifolia

\section{Introduction}

Pollution poses a serious risk to the ecological balance of inshore coral reef systems and has been an important issue in the wider Caribbean region for the last 
two decades (Fernandez et al. 2007; GESAMP 2001; United Nations Environment Program (UNEP) 1994). Heavy metals are major constituents of agrochemicals, industrial pollutants commonly used in ports as well as domestic sewage (Guzmán and Jiménez 1992). They present a serious threat to the marine environment due to their potential toxic effects (Negri and Heyward 2001; Pastorok and Bilyard 1985), wide distribution and capacity for being transported to long distances via atmospheric and hydrological processes (Marx and McGowan 2010; Guzmán and Jiménez 1992).

Heavy metals can result in acute or chronic toxicity causing lethal effects or long-term impacts to key biological processes of corals such as respiration (Howard et al. 1986), fertilisation and metamorphosis (Reichelt-Brushett and Michalek-Wagner 2005; Reichelt-Brushett and Harrison 1999; Negri and Heyward 2001; Heyward 1988) and larvae settlement (Reichelt-Brushett and Harrison 2000; Goh 1991). For example, Heyward (1988) detected the complete inhibition of fertilisation in Goniastrea aspera, Favites chinensis and Platygyra ryukyuensis gametes when exposed to copper sulphate solutions greater than or equal to $0.5 \mathrm{mg} \mathrm{L}^{-1}$. Heavy metals can also result in physiological stress (Howard and Brown 1984), loss of zooxanthellae (Esquivel 1986; Harland and Brown 1989), reduced growth (Howard and Brown 1987), enhanced mortality (Mitchelmore et al. 2007) and reduced biodiversity (Ramos et al. 2004).

Although heavy metals pose a variety of detrimental effects, studies examining heavy metal pollution in corals have received minimal attention worldwide, particularly in the wider Caribbean region. This is of concern since coastal regions of Central America are exposed to a large range of metal pollution from increased environmental contamination (Guzmán and Jiménez 1992). To the best of our knowledge, only three studies examining heavy metal contamination of corals from the wider Caribbean region have been published (Guzmán and García 2002; Guzmán and Jiménez 1992; Bastidas and García 1997). Two of these studies (Guzmán and García 2002; Guzmán and Jiménez 1992) analysed heavy metal concentrations in sediments and coral skeletons (Siderastrea siderea) along the eastern coast of Costa Rica and Panama and indicated intermediate to high levels of pollution (Guzmán and Jiménez 1992). The third study measured nine heavy metals in Montastrea annularis tissues and skeletons (Bastidas and García 1997) and indicated no direct relationship between coral metal concentrations and sedimentation rates.

The objectives of the current study were to determine baseline concentrations and inter-species differences of heavy metals in the tissue of the region's two dominant shallow hard coral species: Porites furcata and Agaricia tenuifolia. Arsenic (As), cadmium $(\mathrm{Cd})$, copper $(\mathrm{Cu})$, zinc $(\mathrm{Zn})$ and mercury $(\mathrm{Hg})$ were analysed as these metals are considered to have the greatest toxic impact of all metals that enter the environment in elevated concentrations (Haynes and Johnson 2000). For this purpose, in situ coral and sediment collection was conducted from coral reef sites along a gradient of increased distance from the Port of Almirante. Results of this study provide further insight into some of the mechanisms influencing heavy metal accumulation in scleractinian corals and will also serve as baseline data for future comparisons of coral reef and sediment contamination by heavy metals within the Bocas del Toro Archipelago.

\section{Materials and methods}

Study area and sampling

Almirante Bay is a semi-enclosed lagoon system (Fig. 1) in the Bocas del Toro Archipelago, which is situated on the Caribbean Sea in Panama. The bay is influenced by ocean conditions via the Boca del Drago inlet situated in the north and experiences a small tidal range of 2-15 cm (Guzmán et al. 2005). A permanent gyre runs (in a counterclockwise direction) south along the coast of Costa Rica and Panama, suggesting long residence times of coastal waters (Guzmán and Jiménez 1992). The Changuinola River is the largest river in proximity to the bay, with the mouth situated approximately $11 \mathrm{~km}$ north-west of the Almirante Bay (Saric 2005). The Changuinola River runs adjacent to mainland banana plantations and discharges sediments into the ocean, which are then transported as a plume into the bay via the Boca del Drago inlet, exiting through the Bocas del Toro Channel and Crawl Cay Channel outlets (Saric 2005). Development is a national priority in the province of Bocas del Toro, and consequently, the marine environment within the bay is severely impacted by sewage discharge, overfishing, 
dredging and a commercial shipping port that is situated close to the mainland and the town of Almirante (Burke et al. 2004; Guzmán and Jiménez 1992). The Port of Almirante exports bananas and is the only industrial source of heavy metals within Almirante Bay.

Coral reef survey sites were chosen based on their proximity to the port: Almirante "AL" $=\sim 1.5 \mathrm{~km}$, Pastores "PA" $=\sim 8 \mathrm{~km}$, Juan Point "JP" $=\sim 10 \mathrm{~km}$, Casa Blanca "CB" $=\sim 18 \mathrm{~km}$ and Salt Creek "SC" $=\sim 35 \mathrm{~km}$ away (Fig. 1). Sampling was conducted three times from November 2010 to January 2011. Due to the lack of background contamination data from this area, coral reef monitoring was conducted throughout the bay using international Reef Check guidelines (Hodgson 2000) to assess the suitability of reefs to be used as experimental sites. Transect monitoring was conducted in replicates of three per reef, at depths of $1-5$ and $6-10 \mathrm{~m}$. Substrate composition, coral diversity and abundance were recorded. Monitoring also provided information on eutrophication based on the presence of high-nutrient indicator species. Water samples (three replicates/sampling) were taken from a 3-m depth using a 2-L Niskin bottle and were immediately analysed for temperature and salinity using a probe (WTW Multiline P4). Sediment samples were taken in cores from the top $10 \mathrm{~cm}$ ( $n=3 /$ sampling period) of substrate surrounding reef sites and oven-dried at $40{ }^{\circ} \mathrm{C}$ for 1 week. Dry sediments were sieved into the size fractions of $<125 \mu \mathrm{m}$.

$P$. furcata was cut using pliers, while $A$. tenuifolia was taken using hammer and chisel. Baseline survey fragments were collected ( $n=15 /$ species) from random colonies between 1- and 6-m depth at all five sites. Due to insufficient tissue mass for analysis, only 1114 fragments could be analysed per site. Sampled fragments were placed in plastic bags and transported on ice to the Smithsonian Tropical Research Institute where they were frozen $\left(-20^{\circ} \mathrm{C}\right)$ until processing. The tissue component of the coral was chosen for heavy metal analyses since metals such as $\mathrm{Zn}$ are important for biological functions and accumulate in greater concentrations in coral tissue relative to skeleton (Anu et al. 2007). In studies comparing both tissue and skeleton components, concentrations of metals in skeletons were typically lower than those recorded in tissues (Howard and Brown 1987; McChonchie and Harriott 1992; Bastidas and García 1997; ReicheltBrushett and McOrist 2003).

Thawed fragments were rinsed thoroughly with filtered seawater to remove sediments and organic debris. Coral tissues were removed from the skeleton with an air gun and a constant volume of filtered seawater. Floating tissues from individual fragments were collected with a sterile dropper and placed into a single, pre-weighed $15-\mathrm{mL}$ centrifuge tube. Remaining tissue slurry was centrifuged at 4,000 rpm (Eppendorf $5810 \mathrm{R}$ ) for $10 \mathrm{~min}$. After centrifugation, the concentrates (tissues and zooxanthellae) were added to the pre-weighed centrifuge tube using a sterile dropper, which was then centrifuged for an additional $5 \mathrm{~min}$ in order to concentrate the remaining suspended tissue components. The supernatant was discarded, and the pre-weighed tube was then oven-dried $\left(60{ }^{\circ} \mathrm{C}\right.$ for approximately $72 \mathrm{~h}$ ) until a constant weight was maintained.

Digestion procedures

Dry tissue and sediment samples were milled using an agate pestle and mortar that was cleaned with $70 \%$ ethanol between each sample. Depending on the sample amount, 50-100 mg of ground tissue and approximately $100 \mathrm{mg}$ of the ground sediments were weighed into Teflon PDS-6 vessels (Heinrichs et al. 1986). Tissues were treated for $1 \mathrm{~h}$ with $1 \mathrm{~mL}$ of $65 \%$ nitric acid $\left(\mathrm{HNO}_{3}\right)$ to oxidise organic matter. Afterwards, $2 \mathrm{~mL}$ of $60 \%$ perchloric acid $\left(\mathrm{HClO}_{4}\right)$ was added and the material was digested in closed vessels for $6 \mathrm{~h}$ at $180^{\circ} \mathrm{C}$. Acids were then evaporated on a heated metal block $\left(180^{\circ} \mathrm{C}\right)$, redissolved and fumed off three times with $2 \mathrm{~mL}$ of diluted hydrochloric acid $(\mathrm{HCl}$, 1 part $\mathrm{HCl}$ to 1 part deionised water). Finally, the samples were diluted to a volume of $2 \mathrm{~mL}$ with $2 \%$ $\mathrm{HNO}_{3}$. Acid digestions of sediments were similar to the methods described for tissues, substituting $3 \mathrm{~mL}$ of $40 \%$ hydrofluoric acid and $1 \mathrm{~mL}$ of $60 \% \mathrm{HClO}_{4}$ instead of $2 \mathrm{~mL}$ of $60 \% \mathrm{HClO}_{4}$ before heating the vessels for $6 \mathrm{~h}$ at $180^{\circ} \mathrm{C}$.

\section{Instrumental analyses}

The heavy metals $\mathrm{As}, \mathrm{Cd}, \mathrm{Cu}$ and $\mathrm{Zn}$ were analysed by inductively coupled plasma optical emission spectrometry (iCAP 6300 Duo, Thermo Fisher Scientific) with detection limits of 1.4, 0.04, 0.24 and $1.2 \mu \mathrm{g} \mathrm{L}^{-1}$, respectively. The interference of $\mathrm{Fe}$ on the $\mathrm{Cd}$ wavelength $214.4 \mathrm{~nm}$ was corrected by measuring the apparent $\mathrm{Cd}$ concentration produced by a pure $\mathrm{Fe}$ solution. Precision and accuracy were checked every 12th sample by analysing the certified reference 


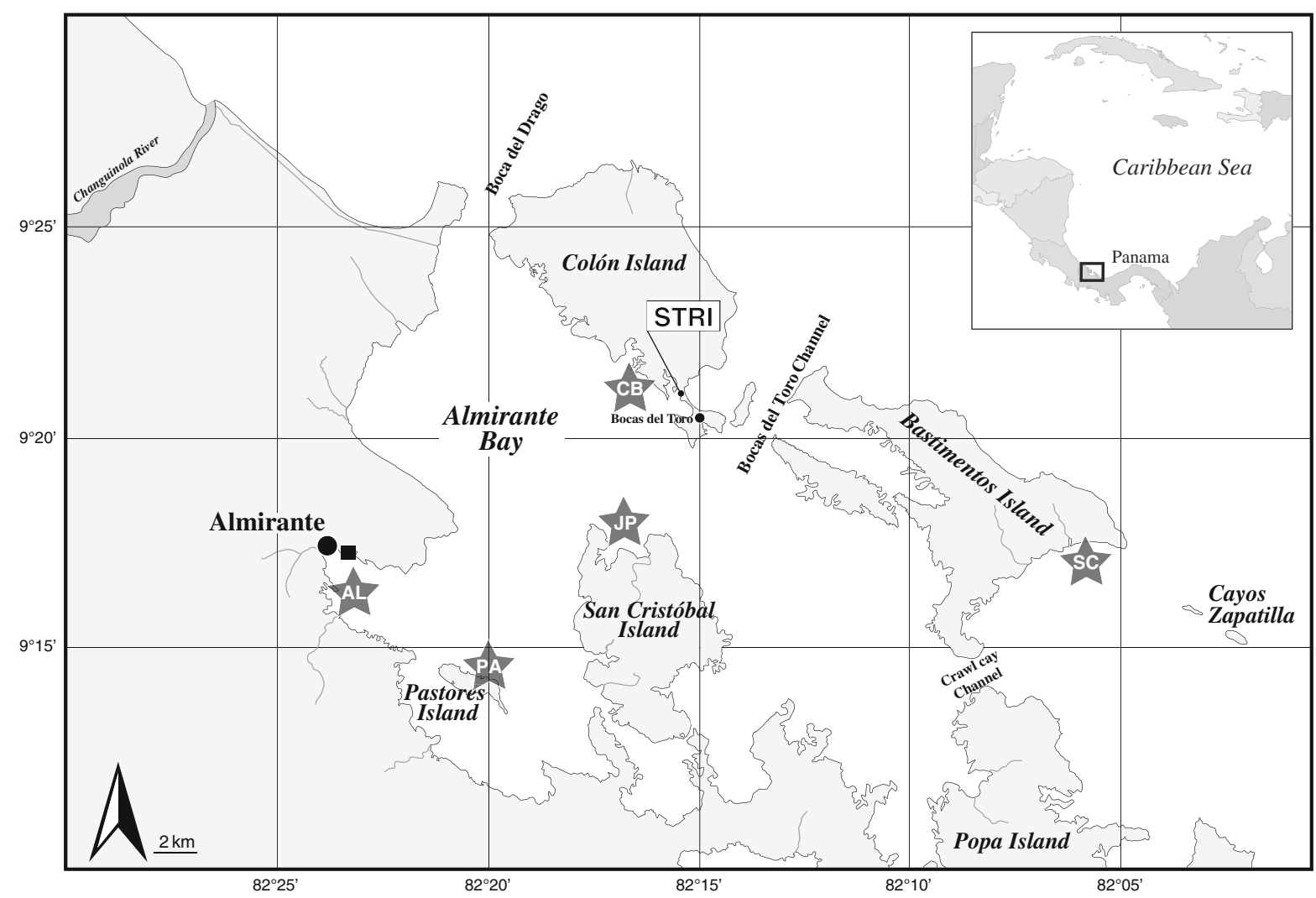

Fig. 1 Survey sites within the Bocas del Toro Archipelago are depicted by grey stars. $A L=$ Almirante, $P A=$ Pastores, $J P=\mathrm{Juan}$ Point, $C B=$ Casa Blanca, $S C=$ Salt Creek, $S T R I=$ Smithsonian Tropical Research Institute. Commercial shipping vessels enter

material TH-2 (Environment Canada, National Water Research Institute, Burlington, Canada) and were $<5.0$ and $<6.4 \%$, respectively. The concentration of $\mathrm{Hg}$ in homogenised dry coral tissues and sediments was analysed using atomic absorption spectrophotometry (Direct Mercury Analyzer 80, Milestone), with an absolute detection limit of $0.0015 \mathrm{ng} \mathrm{Hg}$. Approximately $100 \mathrm{mg}$ of the ground material was pre-weighed in an aluminium boat and transferred to the autosampler of the analytical instrument. A standard and blank were analysed after every 10 samples. The calculated precision and accuracy were 4.0 and $3.4 \%$, respectively.

Data analyses

All analyses were conducted using SigmaStat 11.0 (SYSTAT Software Inc.), with the exception of cluster, for which SPSS version 20 for Windows (Chicago, IL) was used. Normality of data was tested using a the bay through the Boca del Drago inlet in the north and proceed to the Port of Almirante (black square). The town of Almirante is represented by the black circle

Shapiro-Wilk test. Differences in heavy metal concentrations among sites and between species were evaluated using a Kruskal-Wallis one-way ANOVA based on ranks and Dunn's method for post hoc tests. To analyse associations between metal abundance and survey sites, a hierarchical cluster analysis was run for sediments and each species individually. Spearman's rank order correlation was used to determine associations between metal concentrations in corals and distance from the port. All statistical values are presented as means \pm standard error.

\section{Results and discussion}

Environmental parameters

No significant differences were found in temperature $\left(\right.$ mean $\left.=26.8 \pm 0.6{ }^{\circ} \mathrm{C}\right)$ or salinity (mean $=31.8 \pm$ $0.2 \mathrm{~g} \mathrm{~kg}^{-1}$ ) between sampling sites. The mean percent 
of live hard coral cover recorded at the survey sites generally increased with distance from the port (AL, $21.4 \pm 5 \%$; PA, $22.5 \pm 6 \%$; JP, $32.6 \pm 5 \%$; CB, $25.3 \pm$ $8 \%$; SC, $45.9 \pm 2 \%$ ). Hard coral cover at SC was significantly higher than at PA $(p=0.035)$ and $\mathrm{AL}$ $(p=0.033)$. Both $P$. furcata and A. tenuifolia were found in the shallow reef areas at all survey sites with the exception of AL, at which hard coral cover was dominated by $P$. furcata $(>90 \%$ ) and no A. tenuifolia $(0 \%)$ was observed at this reef.

\section{Heavy metals in sediments}

Figure 2 illustrates the mean concentrations of As, Cd, $\mathrm{Cu}, \mathrm{Zn}$ and $\mathrm{Hg}$ in reef sediments. The ranking order of heavy metals in sediments was $\mathrm{Zn}>\mathrm{Cu}>\mathrm{As}>\mathrm{Cd}>\mathrm{Hg}$. Cluster analysis separated sites into three main clusters based on heavy metal concentrations in sediments (Fig. 3a). Metal concentrations at PA, JP and CB were strongly associated to each other, followed by $\mathrm{AL}$. Metal concentrations at SC were weakly associated with the other sites; however, no significant differences were found between sites for any metal. AL contained the highest concentration of $\mathrm{Hg}(22.9 \pm$ $8 \mu \mathrm{g} \mathrm{kg}^{-1}$ ) in sediments, while SC contained the highest concentrations of $\mathrm{Cu}\left(78.6 \pm 31 \mathrm{mg} \mathrm{kg}^{-1}\right)$ and $\mathrm{Zn}\left(79.9 \pm 34 \mathrm{mg} \mathrm{kg}^{-1}\right)$. The concentration of As and $\mathrm{Cd}$ in sediments was very low in comparison to the other metals. The higher concentrations of $\mathrm{Cu}$ and $\mathrm{Zn}$ found at SC (the most offshore site) demonstrate the persistence and long-distance transportation of aquatic pollution from input sources to more remote areas of the marine environment. Other than the Port of Almirante, the only other industrial source of metal pollution in the Bocas del Toro Archipelago is an oil refinery located approximately $40 \mathrm{~km}$ south-west of $\mathrm{SC}$ in the Chiriquí Lagoon. With the exception of $\mathrm{Cu}$, all metals measured in sediments were below contamination levels stated by the US Environmental Protection Agency (Long et al. 1995). Sites AL, PA, JP and SC exceeded the "effects range low" (ERL) guideline value of $\mathrm{Cu}\left(>34 \mathrm{mg} \mathrm{kg}^{-1}\right)$. The ERL is not a threshold limit, but rather the upper range of $\mathrm{Cu}$ concentrations where effects to biota are rarely observed (Long and Morgan 1990). Thus, $\mathrm{Cu}$ adsorbed to sediments within the Almirante Bay could be negatively impacting biota; however, the sediments are considered within natural environmental background levels for As, $\mathrm{Cd}, \mathrm{Zn}$ and $\mathrm{Hg}$.
Studies conducted by Guzmán and Jiménez (1992) and Guzmán and García (2002) measured Cu, Zn, Cd and $\mathrm{Hg}$ concentrations in sediments from sites in proximity to $\mathrm{CB}$, JP and $\mathrm{SC}$. In comparison to their results, the present study found a lower abundance of $\mathrm{Cd}$ and $\mathrm{Hg}$ and higher abundance of $\mathrm{Cu}$ and $\mathrm{Zn}$ in sediments at all sites. Variations found between these studies could be due to changes in levels of pollution discharge over time, availability of metals for adsorption as well as variations in the sampling season.

\section{Comparison of heavy metals in coral tissues}

Mean metal concentrations in coral tissues and significant $(p<0.05)$ inter-site differences between species (ANOVA) are also provided in Fig. 2. The ranking order of heavy metals in coral tissue was $\mathrm{Zn}>\mathrm{Cu}>\mathrm{As}>\mathrm{Cd}>$ $\mathrm{Hg}$, and the highest concentrations of all metals analysed were in $P$. furcata tissues.

Metals are incorporated into corals via three main transport routes: solubilised forms, particulate forms and from food sources through bioaccumulation (Howard and Brown 1984). Although metals in solution are often in biologically available forms, metals in particulate and food phases are considered more important sources to marine organisms because they comprise higher heavy metal concentrations (Bryan 1980). The higher metal loads in P. furcata tissues could be related to differences in feeding mechanisms between the two species. $P$. furcata is more efficient at capturing zooplankton than A. tenuifolia (Lewis and Price 1975), which is more reliant on autotrophy for attaining its energy requirements (Seemann et al. 2012). Although the expansion of mucus nets from $A$. tenuifolia results in the ingestion of large amounts of fine particulate matter (Lewis and Price 1975), which is likely a significant source of heavy metals to this species, zooplankton accumulates metals such as $\mathrm{Cd}, \mathrm{Cu}$ and $\mathrm{Zn}$ that biomagnify in the food web (Pempkowiak et al. 2005).

In comparison with other studies examining heavy metals in coral tissues sampled from reefs situated near marinas, harbours and ports (Table 1), concentrations of $\mathrm{Cd}, \mathrm{Cu}$ and $\mathrm{Zn}$ in the present study were higher than those detected at Heron Island and Wistari Reef in Australia (McChonchie and Harriott 1992). The highest $\mathrm{Cu}$ concentration measured in their study (15 mg kg $\mathrm{mg}^{-1}$ in Goniastrea favulus tissues) was similar to the less contaminated $\mathrm{Cu}$ sites in the Bocas del Toro Archipelago. The mean concentration of $\mathrm{Zn}$ 
Fig. 2 Mean metal concentrations measured in $P$. furcata, A. tenuifolia and sediments at each experimental site in the Bocas del Toro Archipelago. $A L=$ Almirante, $P A=$ Pastores, $J P=$ Juan Point, $C B=$ Casa Blanca, $S C=$ Salt Creek. $*=p<0.05$, intra-site significant differences in tissue metal concentrations between coral species
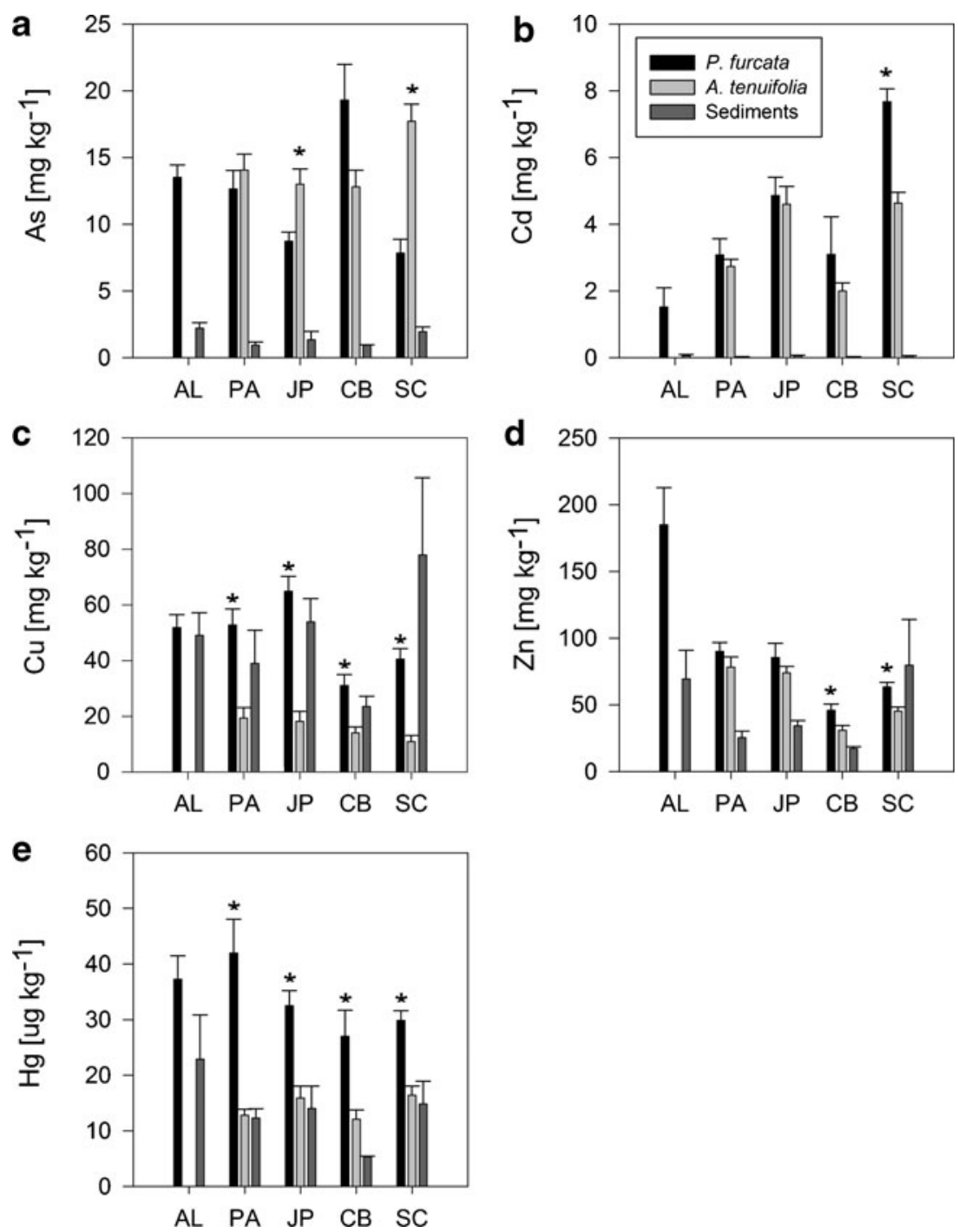

in Pocillopora damicornis (80 $\mathrm{mg} \mathrm{kg}^{-1}$ ) at Heron Island marina was approximately $105 \mathrm{mg} \mathrm{kg}^{-1}$ lower than the highest tissue concentration found in the present study. Similar to our results, the mean $\mathrm{Zn}$ concentration detected in coral tissues from the Heron Island marina was higher (up to five times) than those collected outside the marina area (Wistari Reef). $\mathrm{Cu}$ concentrations were also higher in the tissues of $G$. favulus and Porites spp. at the marina reef. Compared with our results, Esslemont (2000) detected a similar range of $\mathrm{Cd}$ concentrations at two coral reefs in proximity to the Port of Townsville, Australia, while $\mathrm{Cu}$ was generally higher in the present study (Table 1). Tissues of Goniastrea aspera sampled from close proximity to the Port of Townsville were substantially higher in $\mathrm{Zn}\left(\right.$ mean $=900 \mathrm{mg} \mathrm{kg}^{-1}$ ) than coral tissues measured in the present study. However, $\mathrm{Zn}$ in $P$. damicornis and Acropora formosa tissues sampled from Nelly Bay Harbour (15 km offshore from the port) were only slightly higher than the $\mathrm{Zn}$ concentrations detected in P. furcata from AL. Variations in metal concentrations between these studies are related to differences in the types of metal source, the amount of pollution being released into the environment, the proximity of the respective coral reefs to the pollution source and species-specific affinities for metal uptake and storage. For example, the Port of Townsville is the principal port in North Queensland and serves a large area that includes the mining community at Mount Isa and the Greenvale nickel refinery (Queensland Government 2013). The main imports include refined fuel products, nickel ore, etc., while exports include 

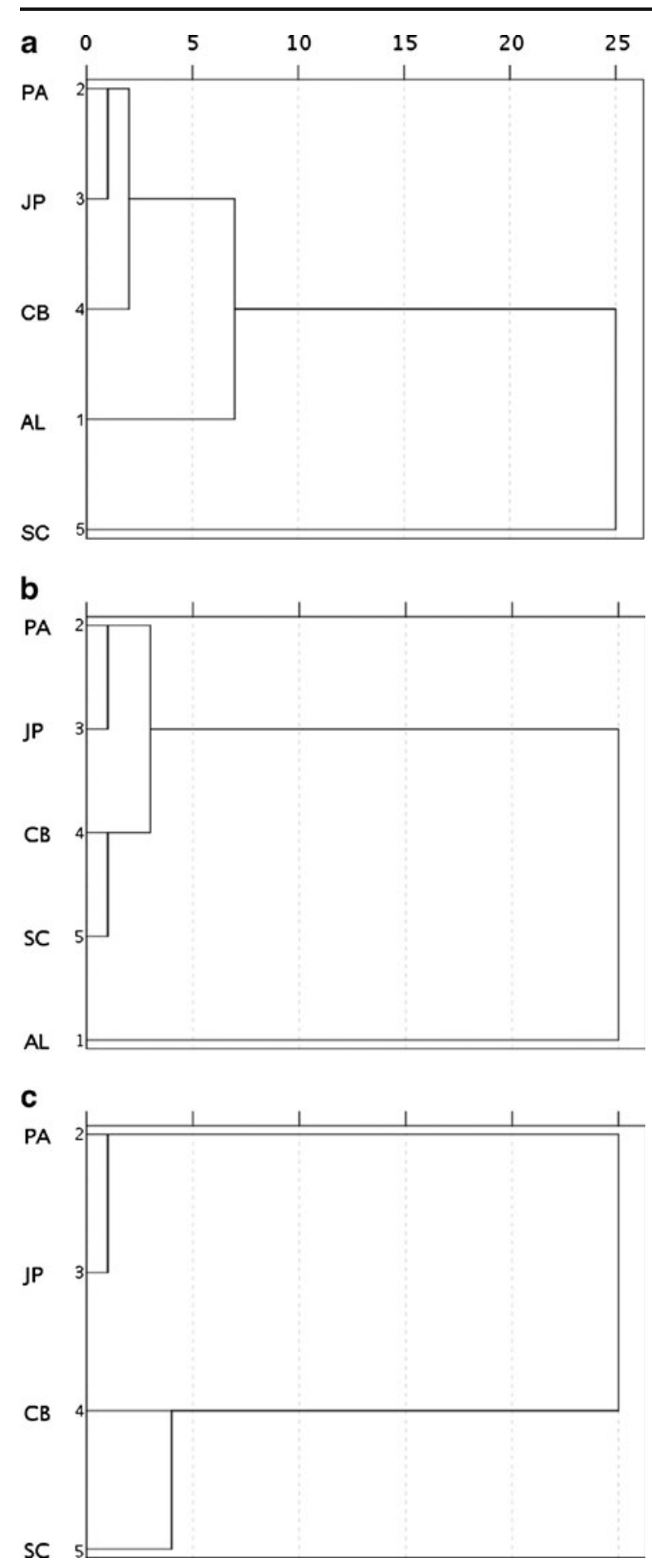

copper and zinc concentrates, refined lead, copper, zinc and nickel (Queensland Government 2013). Thus, metal pollution in the environment surrounding this port can be attributed to many metal-related industries, whereas only port-related activities and
Fig. 3 Cluster analysis dendogram using average linkage between groups ( $x$-axis) to illustrate associations between surveyed coral reef sites ( $y$-axis) based on heavy metal concentrations measured in sediments (a), P. furcata (b) and A. tenuifolia (c) tissues. Site AL is omitted in c since $A$. tenuifolia did not naturally inhabit this site. $A L=$ Almirante, $P A=$ Pastores, $J P=$ Juan Point, $C B=$ Casa Blanca, $S C=$ Salt Creek. Numbers $1-5$ represent the distance gradient of sites from the Port of Almirante, with 1 being the closest and 5 the farthest

antifoulants are the principal sources of metal pollution from the Port of Almirante.

Sources and distribution of heavy metals in coral tissues

Species-specific differences in tissue metal concentrations between sites are summarised in Table 2. A significant negative correlation was found for $\mathrm{As}, \mathrm{Hg}, \mathrm{Cu}$ and $\mathrm{Zn}$ concentrations with distance from the port in $P$. furcata and $\mathrm{Cu}$ and $\mathrm{Zn}$ in A. tenuifolia (Table 3). A significant positive correlation was found for $\mathrm{Cd}$ concentrations in both species. Heavy metal concentrations in coral tissues were separated into three clusters for $P$. furcata (Fig. 3b) and two clusters for A. tenuifolia (Fig. 3c). For both species, the first cluster revealed a strong association in metal concentrations between nearshore coral reef sites, situated in closer proximity to the port and town (PA and JP). The second cluster revealed a strong association of metal concentrations between corals at the more offshore reef sites (CB and SC). For P. furcata, site $\mathrm{AL}$ was weakly associated with the other four sites. This distinction between reefs is likely a result of differences in metal source and the hydrodynamics of the bay.

There are numerous sources of heavy metal pollution throughout Almirante Bay. Point sources include the Port of Almirante, while non-point sources include domestic sewage, agricultural activities and unpredictable sources such as oil waste by tankers (Guzmán and Jiménez 1992). Influence of wind, tides and surf are noticeably reduced inside this semi-lagoon system (Guzmán et al. 2005); thus, the distribution of metal pollution throughout the bay is likely facilitated by the resuspension of dredged sediments, water flow created by the inlet and outlets, discharge from rivers within the bay and the sediment plume originating from the Changuinola River that enters the bay via the Boca del Drago inlet.

The port and town of Almirante, as well as mainland river discharge, are the main pollution sources to nearshore coral reefs in Almirante Bay. AL showed the 
Table 1 Mean heavy metal concentrations in coral tissues from previous marina/harbour/port studies

\begin{tabular}{|c|c|c|c|c|c|}
\hline \multirow[t]{2}{*}{ Species } & \multirow[t]{2}{*}{ Analysis } & \multicolumn{4}{|c|}{ Heavy metal concentration $\left[\mathrm{mg} \mathrm{kg}^{-1}\right]$} \\
\hline & & As \& Hg & $\mathrm{Cd}$ & $\mathrm{Cu}$ & $\mathrm{Zn}$ \\
\hline G. aspera $^{\mathrm{a}}$ & Dry wgt. & - & 2 & 37 & 900 \\
\hline P. damicornis ${ }^{\mathrm{a}}$ & Dry wgt. & - & 6 & 13 & 209 \\
\hline A. formosa ${ }^{\mathrm{a}}$ & Dry wgt. & - & 4 & 12 & 236 \\
\hline A. aspera $^{\mathrm{b}}$ & Wet wgt. & - & 2 & 5 & 71 \\
\hline A. valida ${ }^{\mathrm{b}}$ & Wet wgt. & - & 2 & 3 & 35 \\
\hline P. damicornis ${ }^{\mathrm{b}}$ & Wet wgt. & - & 2 & 4 & 80 \\
\hline G. favulus ${ }^{\mathrm{b}}$ & Wet wgt. & - & 2 & 15 & 60 \\
\hline Porites spp. ${ }^{\mathrm{b}}$ & Wet wgt. & - & 2 & 5 & 52 \\
\hline
\end{tabular}

En dashes indicate that the metal was not analysed

${ }^{\text {a }}$ Source: Esslemont (2000). Comparisons were made using the values from Esslemont's heavy metal extraction procedure A. Values were converted from $\mathrm{nM} \mathrm{g}^{-1}$ to $\mathrm{mg} \mathrm{kg}^{-1}$

${ }^{\mathrm{b}}$ Source: McChonchie and Harriott (1992)

weakest association between all survey sites due to the high $\mathrm{Zn}$ concentrations in $P$. furcata tissues, which were significantly higher $\left(185 \pm 27 \mathrm{mg} \mathrm{kg}^{-1}\right)$ than the concentrations detected at $\mathrm{CB}\left(46 \pm 5 \mathrm{mg} \mathrm{kg}^{-1}\right)$ and $\mathrm{SC}(63 \pm$ $4 \mathrm{mg} \mathrm{kg}^{-1}$, Table 2) and double the second highest mean concentration that was detected at PA $\left(90 \pm 7 \mathrm{mg} \mathrm{kg}^{-1}\right.$, Fig. 2). In general, mean $\mathrm{Zn}$ concentrations were significantly higher at near-shore reef sites compared to the more offshore reef sites for both species (see Table 2), with concentrations at PA and JP approximately double the mean concentrations at $\mathrm{CB}$. Mean $\mathrm{Cu}$ concentrations were also higher at JP, PA and AL compared to $\mathrm{CB}$ and $\mathrm{SC}$ (Fig. 2); however, there were fewer significant differences between sites (Table 2). $\mathrm{Cu}$ and $\mathrm{Zn}$ are the main components in organotin-free antifouling products used to eliminate the settlement of algae and marine invertebrates on ships and are commonly found in high levels around ports and harbours (Negri and Heyward 2001; Turner 2010). These metals are leached uncontrollably into the aquatic environment and antifoulant paint can contaminate sediments, harming many non-target marine invertebrates such as corals (Negri and Heyward 2001; Negri et al. 2002; Smith et al. 2003). Metals are also released into the marine environment at ports as a result of oil spills during terminal transfers and fuel discharge (Guzmán and Jiménez 1992).

Table 2 Significant differences found in P. furcata and (A. tenuifolia) tissues for each metal between sampling sites

\begin{tabular}{|c|c|c|c|c|c|c|}
\hline Metal & Sites & Almirante & Pastores & Juan Point & Casa Blanca & Salt Creek \\
\hline \multirow[t]{2}{*}{ As } & Juan Point & $*$ & $*$ & $*$ & $p<0.05$ & $*$ \\
\hline & Salt Creek & $p<0.05$ & * & $*$ & $p<0.05$ & $*$ \\
\hline \multirow[t]{3}{*}{$\mathrm{Cd}$} & Almirante & $*$ & $*$ & $p<0.05$ & $*$ & $p<0.05$ \\
\hline & Pastores & $*$ & $*$ & $(p<0.05)$ & $*$ & $p<0.05(p<0.05)$ \\
\hline & Casa Blanca & $*$ & $*$ & $(p<0.05)$ & $*$ & $p<0.05(p<0.05)$ \\
\hline \multirow[t]{2}{*}{$\mathrm{Cu}$} & Casa Blanca & $*$ & $*$ & $p<0.05$ & $*$ & $*$ \\
\hline & Salt Creek & $*$ & $(p<0.05)$ & $*$ & $*$ & $*$ \\
\hline \multirow[t]{2}{*}{$\mathrm{Zn}$} & Casa Blanca & $p<0.05$ & $p<0.05(p<0.05)$ & $(p<0.05)$ & $*$ & $*$ \\
\hline & Salt Creek & $p<0.05$ & $(p<0.05)$ & $(p<0.05)$ & $*$ & $*$ \\
\hline
\end{tabular}

Corals sampled from sites listed on the top row are significantly higher than those from sites listed in the column and should be read accordingly. Sites and metals that showed no significant differences were omitted

${ }^{*} p>0.05$ (not significantly different) 
Inhibition of fertilisation and metamorphosis was observed in Acropora millepora after exposure to antifoulants and $\mathrm{Cu}$ (Negri and Heyward 2001). $\mathrm{Cu}$ concentrations of 42 and $81 \mu \mathrm{g} \mathrm{L}^{-1}$ significantly reduced the settlement success of Acropora tenuis larvae after $48 \mathrm{~h}$ of exposure (Reichelt-Brushett and Harrison 2000). $\mathrm{Zn}$ is important for coral photosynthesis and calcification; however, it can be toxic at high concentrations (Ferrier-Pagès et al. 2005). Heyward (1988) found that $\mathrm{Zn}$ sulphate concentrations of $1,000 \mu \mathrm{g} \mathrm{L}^{-1}$ reduced fertilisation rates of $P$. ryukyuensis and $F$. chinensis gametes. Direct comparisons cannot be made to these studies since the concentration of heavy metals in seawater was not analysed in the present study. However, the elevated $\mathrm{Cu}$ and $\mathrm{Zn}$ concentrations detected in sediments and coral tissue suggest that these metals could be the contributing factors to the reduced hard coral cover and diversity recorded at reefs in proximity to the port.

Although a significant negative correlation was found for $\mathrm{Hg}$ concentrations in P. furcata tissues with distance from the port, no clear pattern of distribution was found for $\mathrm{Hg}$ in A. tenuifolia (Table 3). $\mathrm{Hg}$ is not an essential element for biological functions, and any accumulation of $\mathrm{Hg}$ is considered as contamination and potentially hazardous (National Research Council 2000). A potential issue of concern is that $\mathrm{Hg}$ is known to biomagnify through trophic levels (United States Environmental Protection Agency 1997) and corallivorous fish from Almirante Bay, such as parrotfish, are being consumed by humans (personal observation).

Concentrations of $\mathrm{Cd}$ in coral tissue showed a significant positive correlation with distance from the port (Table 3). Low Cd content within corals located near ports and harbours has also been observed in other studies (McChonchie and Harriott 1992; Esslemont 2000) and was attributed to differences in water circulation and current distribution (McChonchie and Harriott 1992), as well as tissue regulation through assimilation of $\mathrm{Cd}$ into coral skeletons (Esslemont
2000). Heavy metals interact and compete for chemically similar ions when in solution (Ray 1986). The addition of $\mathrm{Zn}$ to seawater with $\mathrm{Cd}$ resulted in decreased $\mathrm{Cd}$ levels in the bivalves Mytilus edulis and Mulinia lateralis (Jackim et al. 1977). Thus, higher Zn levels in the port vicinity could account for the lower Cd concentrations measured in coral tissue.

The more offshore sites (CB and SC) generally contained lower concentrations of $\mathrm{Cu}$ and $\mathrm{Zn}$, but higher concentrations of $\mathrm{As}$ ( $\mathrm{CB}$ and $\mathrm{SC}$ ) and $\mathrm{Cd}$ (SC). Potential sources of $\mathrm{Cd}$ and As to these reefs are sewage discharge from the highly developed and touristic Colón Island and biocides and fertilisers from river run-off entering the Boca del Drago inlet via the sediment plume. Metals are adsorbed to sediment particles, which play a significant role in their transport from pollution sources (Förstner and Salomons 1980). The higher metal concentrations found at SC compared to $\mathrm{CB}$ demonstrate that even remote coral reefs are influenced by metal pollution due to long-distance transport and persistence of metals in the marine environment. It is possible that $\mathrm{SC}$ is also being influenced by the oil refinery located to its south in the Chiriquí Lagoon. Due to the locality of these sites relative to the inlet $(\mathrm{CB})$ and the open ocean $(\mathrm{SC})$, higher water flow rates would result in a lower retention time of pollutants at $\mathrm{CB}$ and SC compared to the other sites and supports our finding of lower tissue concentrations of most metals detected at these sites (Fig. 2).

\section{Conclusions}

All of the surveyed coral reef sites within Almirante Bay and the surrounding archipelago are being influenced by heavy metal pollution; however, the near-shore coral reefs are at a greater risk from $\mathrm{Cu}$, $\mathrm{Zn}$ and $\mathrm{Hg}$ pollution than the more offshore coral reefs. $\mathrm{Cu}$ and $\mathrm{Zn}$ are the most abundant metals in Almirante Bay, and antifoulants and port-related

Table 3 Correlation coefficients between mean tissue heavy metal concentrations and increasing distance from the Port of Almirante

\begin{tabular}{llllllll}
\hline Species & Correlation coeff. & Number & As & Cd & Cu & Zn & Hg \\
\hline P. furcata & $r$ & 57 & -0.34 & +0.68 & -0.27 & -0.66 & -0.29 \\
& $p$ value & & $p=0.01$ & $p<0.001$ & $p=0.04$ & $p<0.001$ & $p=0.04$ \\
A. tenuifolia & $r$ & \multirow{2}{*}{38} & +0.30 & +0.49 & -0.49 & -0.65 & +0.22 \\
& $p$ value & & $p=0.068$ & $p=0.003$ & $p=0.002$ & $p<0.001$ & $p=0.224$ \\
& & & & & &
\end{tabular}


activities are largely influencing $\mathrm{Cu}$ and $\mathrm{Zn}$ pollution to nearby coral reefs. These metals have increased in reef sediments over the last two decades, and currently, four out of the five survey sites exceed the ERL guideline value of $\mathrm{Cu}$ in sediments, meaning that the health of biota inhabiting these reefs could be at risk. The lower hard coral abundance and diversity at coral reefs in closer proximity to the port shows that these reefs are suffering from degraded environmental conditions and that management of these important ecosystems is required.

Acknowledgments We thank R. Collin, H. Guzmán, P. Gondola, G. Jacome and E. Brown (Smithsonian Tropical Research Institute, Panama) for help with administrative, field and laboratory work. Thanks are due to E. Kuhl (Museum für Naturkunde, Berlin) for her help with all laboratory logistics, D. Benesch (Leibniz Institute for Baltic Sea Research, Rostock) for assistance in conducting metal analyses, G. Heiss (Freie Universität Berlin) for field trip logistics and figure formatting, and K. Fabricius, P. Bürger and the reviewers and editorial team at EMAS for reviewing this paper. This research was assisted by Pawel Rammingen Stiftung.

Open Access This article is distributed under the terms of the Creative Commons Attribution License which permits any use, distribution, and reproduction in any medium, provided the original author(s) and the source are credited.

\section{References}

Anu, G., Kumar, N. C., Jayalakshmi, K. J., \& Nair, S. M. (2007). Monitoring of heavy metal partitioning in reef corals of Lakshadweep Archipelago, Indian Ocean. Journal of Environmental Monitoring and Assessment, 128, 195-208.

Bastidas, C., \& García, E. (1997). Metal concentration in the tissue and skeleton of the coral Montastrea annularis at a Venezuelan reef. In H.A. Lessios, \& I.G. Macintyre (Eds.) Proceedings of the 8th International Coral Reef Symposium (Vol 2 pp. 1847-1850). Panama: Smithsonian Tropical Research Institute.

Bryan, G. W. (1980). Recent trends in research on heavy-metal contamination in the sea. Helgoländer Meeresuntersuchungen, $33,6-25$.

Burke, L., Maidens, J., Spalding, M., Kramer, P., Green, E., Greenhalgh, S., et al. (2004). Reefs at risk in the Caribbean. Washington DC: World Resources Institute.

Esquivel, I.F. (1986). Short term copper bioassay on the planula of the reef coral Pocillopora damicornis. In P.L. Jokiel, R.H. Richmond, \& R.A. Rogers (Eds.) Coral reef population biology (pp. 469-472). Technical Report 37, Hawaii Institute of Marine Biology, Coconut Island, HI, USA.

Esslemont, G. (2000). Heavy metals in seawater, marine sediments and corals from the Townsville section, Great
Barrier Reef Marine Park, Queensland. Marine Chemistry, 71, 215-231.

Fernandez, A., Singh, A., \& Jaffé, R. (2007). A literature review on trace metals and organic compounds of anthropogenic origin in the Wider Caribbean Region. Marine Pollution Bulletin, 54, 1681-1691.

Ferrier-Pagès, C., Houlbrèque, F., Wyse, E., Richard, C., Allemand, D., \& Boisson, F. (2005). Bioaccumulation of zinc in the scleractinian coral Stylophora pistillata. Coral Reefs, 24, 636-645.

Förstner, U., \& Salomons, W. (1980). Trace metal analysis on polluted sediments. Part 1: assessment of sources and intensities. Environmental Technology Letters, 11, 494-505.

GESAMP (IMO/FAO/UNESCO-IOC/WMO/WHO/IAEA/UN/ UNEP Joint Group of Experts on the Scientific Aspects of Marine Environmental Protection) and Advisory Committee on Protection of the Sea. (2001). Protecting the oceans from land-based activities-land-based sources and activities affecting the quality and uses of the marine, coastal and associated freshwater environment. Rep. Stud. GESAMP No. 71, 162 pp.

Goh, B. L. (1991). Mortality and settlement success of Pocillopora damicornis planula larvae during recovery from low levels of nickel. Pacific Science, 45(3), 276-286.

Guzmán, H. M., \& García, E. M. (2002). Mercury levels in coral reefs along the Caribbean coast of Central America. Marine Pollution Bulletin, 44, 1415-1420.

Guzmán, H. M., \& Jiménez, C. E. (1992). Contamination of coral reefs by heavy metals along the Caribbean coast of Central America (Costa Rica and Panama). Marine Pollution Bulletin, 24, 554-561.

Guzmán, H. M., Barnes, P. A. G., Lovelock, C. E., \& Feller, I. C. (2005). A site description of the CARICOMP mangrove, seagrass and coral reef sites in Bocas del Toro, Panama. Caribbean Journal of Science, 41, 430-440.

Harland, A. D., \& Brown, B. E. (1989). Metal tolerance in the scleractinian coral Porites lutea. Marine Pollution Bulletin, 20, 353-357.

Haynes, D., \& Johnson, J. E. (2000). Organochlorine, heavy metal and polyaromatic hydrocarbon pollutant concentrations in the Great Barrier Reef (Australia) environment: a review. Marine Pollution Bulletin, 41, 267-278.

Heinrichs, H., Brumsack, H. J., Loftfield, N., \& König, N. (1986). Verbessertes Druckaufschlußsystem für biologische und anorganische Materialien. Zeitschrift für Pflanzenernährung und Bodenkunde, 149, 350-353.

Heyward, A.J. (1988). Inhibitory effects of copper and zinc sulphates on fertilization in corals. In J.H. Choat, D. Barnes, M.A. Borowitzka, J.C. Coll, P.J. Davies, P. Flood, et al. (Eds.) Proceedings of the 6th International Coral Reef Symposium (Vol. 2, pp. 299-303). Townsville, Australia.

Hodgson, G. (2000). Coral reef monitoring and management using Reef Check. Integrated Coastal Zone Management, 1, 169-179.

Howard, L. S., \& Brown, B. E. (1984). Heavy metals and reef corals. Oceanography and Marine Biology Annual Review, 22, 195-210.

Howard, L. S., \& Brown, B. E. (1987). Metals in Pocillopora damicornis exposed to tin smelter effluent. Marine Pollution Bulletin, 18, 451-454. 
Howard, L. S., Crosby, D.G., \& Alino, P. (1986). Evaluation of some methods for quantitatively assessing the toxicity of heavy metals to corals. In P.L. Jokiel, R.H. Richmond, \& R.A. Rogers (Eds.) Coral reef population biology. Hawaii Inst. Mar. Biol. Tech. Rep. No. 37, pp. 501.

Jackim, E., Morrison, G., \& Steele, R. (1977). Effects of environmental factors on radiocadmium uptake by four species of marine bivalves. Marine Biology, 40, 303-308.

Lewis, J. B., \& Price, W. S. (1975). Feeding mechanisms and feeding strategies in Atlantic reef corals. Journal of Zoology London, 176, 527-544.

Long, E.R., Morgan, L.G. (1990). The potential for biological effects of sediment-sorbed contaminants tested in the national status and trends program. NOAA technical memorandum NOS OMA 52, Seattle, WA, 175 pp. and appendices

Long, E. R., MacDonald, D. D., Smith, S. L., \& Calder, F. D. (1995). Incidence of adverse biological effects within ranges of chemical concentrations in marine and estuarine sediments. Environmental Management, 19, 81-97.

Marx, S. K., \& McGowan, H. A. (2010). Long-distance transport of urban and industrial metals and their incorporation into the environment: sources, transport pathways and historical trends. In F. Zereini \& C. L. S. Wiseman (Eds.), Urban airborne particulate matter: origin, chemistry, fate and health impacts. Berlin: Springer.

McChonchie, D., \& Harriott, V.J. (1992). The partitioning of metals between tissue and skeletal parts of corals: application in pollution monitoring. In R.H. Richmond (Ed.) Proceedings of the 7th International Coral Reef Symposium (Vol. 1, pp. 97-103). UOG Station, Guam: University of Guam Press.

Mitchelmore, C. L., Verde, E. A., \& Weis, V. M. (2007). Uptake and partitioning of copper and cadmium in the coral Pocillopora damicornis. Aquatic Toxicology, 85, 48-56.

National Research Council. (2000). Toxilogical effects of methyl mercury. Washington, DC: National Academy of Sciences Press. 334.

Negri, A. P., \& Heyward, A. J. (2001). Inhibition of coral fertilisation and larval metamorphosis by tributyltin and copper. Marine Environmental Research, 51, 17-27.

Negri, A. P., Smith, L. D., Webster, N. S., \& Heyward, A. J. (2002). Understanding ship-grounding impacts on coral reef: potential effects of anti-foulant paint contamination on coral recruitment. Marine Pollution Bulletin, 44, 111-117.

Pastorok, R. A., \& Bilyard, G. R. (1985). Effects of sewage pollution on coral-reef communities. Marine Ecology Progress Series, 21, 175-189.

Pempkowiak, J., Walkusz-Miotk, J., Beldowski, J., \& Walkusz, W. (2005). Heavy metals in zooplankton from the southern Baltic. Chemosphere, 62(10), 1697-1708.
Queensland Government (2013). Port procedures and information for shipping Port of Townsville. http://www.msq.qld.gov.au/ / media/msqinternet/msqfiles/home/shipping/port\%20procedures/ townsvilleppm/townsvilleppm.pdf. Accessed 07 Mar 2013.

Ramos, A. A., Inoue, Y., \& Ohde, S. (2004). Metal concentrations in Porites corals: anthropogenic input of river run-off into a coral reef from an urbanized area, Okinawa. Marine Pollution Bulletin, 48, 281-294.

Ray, S. (1986). Bioaccumulation of cadmium in marine organisms. Experientia. Supplementum, 40, 65-75.

Reichelt-Brushett, A. J., \& Harrison, P. L. (1999). The effect of copper, zinc and cadmium on fertilization success of gametes from scleractinian reef corals. Marine Pollution Bulletin, 38, 182-187.

Reichelt-Brushett, A. J., \& Harrison, P. L. (2000). The effect of copper on the settlement success of larvae from the scleractinian coral Acropora tenuis. Marine Pollution Bulletin, 41, 385-391.

Reichelt-Brushett, A. J., \& McOrist, G. (2003). Trace metals in the living and nonliving components of scleractinian corals. Marine Pollution Bulletin, 46, 1573-1582.

Reichelt-Brushett, A. J., \& Michalek-Wagner, K. (2005). Effects of copper on the fertilization success of the soft coral Lobophytum compactum. Aquatic Toxicology, 74, 280284.

Saric, M. B. (2005). Sedimentologie und Geobiologie von Riffassoziationen in der Bahia Almirante (Archipel von Bocas del Toro, Panamá) (pp. 1-193). LudwigMaximilians-Universität: Dissertation.

Seemann, J., Carballo-Bolanos, R., Berry, K.L., González, C.T., Richter, C., \& Leinfelder, R.R. (2012). Importance of heterotrophic adaptations of corals to maintain energy reserves. In Proceedings of the 12th International Coral Reef Symposium, Cairns, Australia, 19A.

Smith, L. D., Negri, A. P., Philipp, E., Webster, N. S., \& Heyward, A. J. (2003). The effects of antifoulant-paintcontaminated sediments on coral recruits and branchlets. Marine Biology, 143, 651-657.

Turner, A. (2010). Marine pollution from antifouling paints. Marine Pollution Bulletin, 60, 159-171.

United Nations Environment Program (UNEP). (1994). Regional overview of land-based sources of pollution in the Wider Caribbean Region. CEP technical report no. 33. UNEP Caribbean Environmental Program, Kingston.

United States Environmental Protection Agency. (1997). Mercury study report to congress. Volume 3: fate and transport of mercury in the environment (p. 376). Washington, D.C.: United States Environmental Protection Agency. 